\title{
MANAJEMEN STRATEGI GURU DALAM MENUMBUHKAN KESADARAN SISWA UNTUK MEMPERTAHANKAN PROGRAM ADIWIYATA DI MADRASAH TSANAWIYAH NEGERI 2 PAMEKASAN
}

\author{
Ahmad Rofiqi dan Usman \\ Fakultas Tarbiyah IAIN Madura \\ Email:Ahmadrofiqi1998@gmail.com dan ualadipni@gmail.com
}

\begin{abstract}
Abstrak
Manajemen strategi merupakan serangkaian proses atau tahapan. Proses manajemen strategi menyediakan kerangka gabungan bagi para manajer untuk menangani berbagai masalah yang unik untuk mengidentifikasi peluang baru dengan lebih mudah dan untuk memperkirakan kekuatan yang dapat digunakan dan kelemahan yang harus diperbaiki. Penelitian ini menggunakan pendekatan kualitatif dengan jenis deskriptif yang sumber data yang diperoleh melalui wawancara, observasi dan dokumentasi. Hasil penelitian menunjukkan bahwa Manajemen strategi guru dalam menumbuhkan kesadaran siswa untuk mempertahankan program adiwiyata yaitu 1) Perencanaan 2) Pelaksanaan 3) Evaluasi setiap 3 bulan satu kali. Adapun faktor pendukungnya yaitu: 1) Kerjasama dan sama kerja antara seluruh elemen sekolah, 2) Mengikuti peraturan yang ada disekolah 3) Menciptakan POKJA, 4) membentuk jadwal piket pemantau kebersihan, 5) Siswa memang berasal dari sekolah dasar adiwiyata, 6) Semua guru menerapkan program adiwiyata kedalam pembelajaran dan kehidupan berorganisasi. Faktor Penghambatnya yaitu : 1) Ketidak pedulian guru terhadap program dan perilaku yang mengarah kepada program adiwiyata, 2) Faktor keluarga.
\end{abstract}

Kata Kunci: Manajemen Strategi Guru, Kesadaran Siswa, Program Adiwiyata.

\begin{abstract}
Strategic management is a series of processes or stages. The strategic management process provides managers with a combined framework for dealing with a variety of unique problems to identify new opportunities more easily and to estimate the strengths that could be used and weaknesses that should be corrected. This research uses a qualitative approach with descriptive type, the source of which is data obtained through interviews, observation, and documentation. The results showed that the teacher's strategic management in growing students' awareness to maintain Adiwiyata program, namely 1) Planning 2) Implementation 3) Evaluation every 3 months once. The supporting factors are: 1) Cooperation and cooperation between all elements of the school, 2) Following the existing regulations in school 3) Creating POKJA, 4) forming a picket schedule to monitor cleanliness, 5) Students do come from Adiwiyata elementary schools, 6) All teachers applying the Adiwiyata program to learning and organizational life. Inhibiting factors, namely: 1) The teacher's ignorance of the program and behavior that leads to the Adiwiyata program, 2) Family factors.
\end{abstract}

Keywords: Teacher Strategy Management, Student Awareness, Adiwiyata Program. 


\section{PENDAHULUAN}

Kesadaran lingkungan dan pemahaman tentang pengelolaan lingkungan diberikan melalui pendidikan lingkungan hidup. Pada awalnya, pendidikan lingkungan hidup bermula dari kepedulian dan kegundahan berbagai pihak atas permasalahan lingkungan yang ada. Khususnya yang terjadi setelah era industri sekitar tahun 1950-an yang kemudian berdampak nyata pada permasalahan lingkungan seperti pencemaran lingkungan pada tahun 1960-an. Sehingga banyak para ahli yang mempertimbangkan dan memikirkan sebuah kerangka kerja pendidikan untuk memberi pemahaman banyak orang mengenai lingkungan. Hal ini sejalan dengan Gough \& Gough dan Stapp yang menjabarkan bahwa definisi awal pendidikan lingkungan hidup bertujuan untuk menghasilkan masyarakat yang memiliki pengetahuan tentang lingkungan biofisik dan permasalahannya, sadar untuk menyelesaikan permasalahan lingkungan tersebut dan termotivasi untuk bekerja dalam mengatasi masalah lingkungan tersebut. ${ }^{1}$

Pendidikan yang diterapkan di lingkungan internal sistem kelembagaan hanyalah sebagian dari tanggung jawab kepala lembaga pendidikan sebagai manajer pendidikan Para pengelola lembaga pendidikan merupakan eksekutif modern saat ini harus mampu mengamati dan merespon segenap tantangan yang dimunculkan oleh lingkungan eksternal baik yang dekat maupun yang jauh. Lingkungan eksternal dekat adalah lingkungan yang mempunyai pengaruh langsung pada operasional lembaga pendidikan, seperti berbagai potensi dan keadaan dalam bidang pendidikan yang menjadi konsentrasi usaha sekolah itu sendiri, situasi persaingan, situasi pelanggan pendidikan, dan pengguna lulusan. Kesemuanya berpengaruh pada penentuan strategi yang diperkirakan mendukung penyelenggaraan pendidikan mencapai tujuannya. Lingkungan eksternal yang jauh adalah berbagai kekuatan dan kondisi yang muncul di luar lingkungan eksternal yang dekat meliputi keadaan sosial ekonomi, politik, keamanan nasional, perkembangan teknologi, dan tantangan global. Secara tidak langsung berpengaruh terhadap penyelenggaraan sistem pendidikan di suatu lembaga pendidikan. $^{2}$

Manajemen adalah proses perencanaan, pengorganisasian, pengarahan, dan pengawasan usaha-usaha para anggota organisasi dan penggunaan sumber daya organisasi lainnya agar mencapai tujuan organisasi yang telah ditetapkan. ${ }^{3}$ Perencanaan Pendidikan adalah suatu penerapan yang rasional dianalisis secara sistematis mengenai proses perkembangan Pendidikan dengan tujuan agar Pendidikan itu lebih efektif dan efisien serta sesuai dengan kebutuhan dan tujuan para peserta didik dan masyarakat. ${ }^{4}$

Dalam dunia pendidikan, strategi diartikan sebagai "a plan, method, or series of activities designed to achieves a particular educational goal" yang artinya rencana, metode, atau rangkaian kegiatan yang dirancang untuk mencapai tujuan pendidikan tertentu.

\footnotetext{
${ }^{1}$ Anisa Muslicha. "Metode Pengajaran dalam Pendidikan Lingkungan Hidup pada Siswa Sekolah Dasar pada Sekolah Adiiyata di DKI Jakarta" Jurnal Pendidikan Volume 16, Nomor 2 (2015), 111.

2 Muhamad Khoirul Umam, "Analisis Lingkungan Strategik dalam Corak Penyelenggaraan Pendidikan Islam” Jurnal Al-Hikmah Volume 4, Nomor 2 (2016), 01.

${ }^{3}$ Hani Handoko. Manajemen, (Yogyakarta: Anggota IKAPI, 2009), 08.

${ }^{4}$ Aep Kusnawan. "Perencanaan Pendidikan Tinggi Dakwah Islam" Jurnal Ilmu Dakwah Volume 4, Nomor 15 (2010), 903.
} 
Manajemen strategi merupakan serangkaian proses atau tahapan. Proses manajemen strategi menyediakan kerangka gabungan bagi para manajer untuk menangani berbagai masalah yang unik untuk mengidentifikasi peluang baru dengan lebih mudah dan untuk memperkirakan kekuatan yang dapat digunakan dan kelemahan yang harus diperbaiki. Proses ini dimaksudkan untuk memadukan antara misi dan tujuan yang dihubungkan dengan lingkungan internal dan eksternal, kekuatan, kelemahan, ancaman dn peluang untuk memilih strategi yang tepat dan menentukan tercapainya strategi yang diinginkan. ${ }^{5}$

Guru sebagai pendidik ataupun pengajar merupakan factor penentu kesuksesan setip usaha pendidikan. Itulah sebabnya setiap perbincangan mengenai pembaruan kurikulum, pengadaan alat-alat belajar sampai pada criteria sumber daya manusia yang dihasilkan oleh usaha pendidikan, selalu bermuara pada guru. Hal ini menunjukkan betapa signifikan posisi guru dalam dunia pendidikan. ${ }^{6}$

Kesadaran Siswa merupakan sikap mental siswa dalam memandang sesuatu. Dalam sikap mental ini maka siswa akan berprilaku sebagaimana sikap mental yang dianutnya. Seperti halnya siswa mempunyai kesadaran bahwa lingkungan yang bersih akan menjamin proses belajar mengajar yang berlangsung di lembaga pendidikan tersebut akan menjadi lebih efektif, sehingga seluruh warga sekolah berupaya untuk selalu menjaga dan mempertahankan kebersihan lingkungan sekolah.

Lingkungan hidup adalah kesatuan ruang dengan semua benda, daya, keadaan, dan makhluk hidup, termasuk di dalamnya manusia dengan perilakunya, yang mempengaruhi kelangsungan perikehidupan dan kesejahteraan manusia serta makhluk hidup lainnya. $^{7}$

Indonesia dapat dikatakan sebagai negara yang memiliki potensi bencana alam yang cukup besar seperti gempa bumi, gunung meletus, dan tsunami. Sebagian dari bencana tersebut merupakan akibat proses alami yang terkait dengan ulah manusia, baik secara langsung (seperti banjir, kekeringan, dan tanah longsor),maupun yang tidak langsung (seperti banjir pasang akibat penurunan permukaan tanah daerah pantai). Akibat yang ditanggung dari bencana alam tersebut selainmengalami kerugian material, juga menciptakan suatu kondisi krisis lingkungan.

Kondisi krisis lingkungan sendiri sebenarnya muncul karena kelalaian manusia itu sendiri. Kegiatan manusia dengan mengeksploitasi sumber daya yang disediakan lingkungan untuk menjadi bekal akan kebutuhan manusia mungkin masih dianggap suatu kewajaran demi menjaga kelangsungan hidup. Namun tindakan tersebut dinilai menjadi salah apabila kebutuhannya tidak pernah tercukupi dan memperlakukan alam berdasarkan keinginan sendiri. Hal ini tentunya akan mengganggu keseimbangan alam dan lingkungan hidup sekitar.

Seiring dengan perubahan peradaban, kebutuhan terus berkembang baik jenis maupun jumlahnya, sedangkan penyediaan sumber daya alam terbatas. Eksploitasi yang berlebihan akan mengakibatkan merosotnya daya dukung lingkungan. Namun

\footnotetext{
5 Amirullah. Manajemen Strategi Teori-Konsep-Kinerja, (Jakarta: Mitra Wacana Media, 2015), 15.

${ }^{6}$ Muhibbin Syah. Psikologi Pendidikan (Bandung: PT. Remaja Rosdakarya, 2009), 222-223.

${ }^{7}$ Ika Maryani. "Evalusi Pelaksanaan Program Sekolah Adiwiyata ditinjau dari Aspek Kegiatan Partisipatif di SDN Ungaran 1 Yogyakarta" Jurnal Pemikiran dan Pengembangan SD Volume 1, Nomor 3 (2014), 172.
} 
setidaknya, manusia berkewajiban untuk menyelamatkan lingkungan sebagai antisipasi memperlambat laju peningkatan suhu bumi.

Jika kita renungkan lebih mendalam kerusakan lingkungan hidup di atas, sejalan dengan apa yang telah dicantumkan Allah dalam Al-qur'an surat Al-rum ayat 41 :

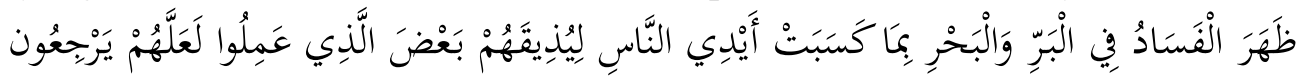

Artinya :"Telah nampak kerusakan di darat dan di laut disebabkan karena perbuatan tangan manusia, supaya Allah menjadikan mereka sebagian dari (akibat) perbuatan mereka, agar mereka kembali (ke jalan yang benar)."

Dengan demikian, dalam persoalan lingkungan hidup manusia mempunyai peranan yang sangat penting. Karena pengelolaan lingkungan hidup sendiri pada akhirnya ditunjukan untuk kelangsungan manusia di bumi ini. Melihat persoalan pengelolaan lingkungan tersebut pemerintah juga berkomitmen dalam menjaga lingkungan dari kerusakan melalui pendidikan. Jadi konsep dasar lingkungan hidup menjelaskan kepada kita bahwa hidup manusia tergantung pada lingkungannya. ${ }^{8}$

Untuk mendukung Perlindungan dan Pengelelolaan Lingkungan Hidup melalui pendidikan di sekolah, maka Kementerian Lingkungan Hidup bekerjasama dengan Kementerian Pendidikan dan Kebudayaan untuk mengembangkan program pengelolaan lingkungan yang disebut program Adiwiyata.

Program Adiwiyata adalah salah satu program Kementrian Negara Lingkungan Hidup dalam rangka mendorong terciptanya pengetahuan dan kesadaran warga sekolah dalam upaya pelestarian lingkungan hidup. Dalam pelaksanaannya Kementrian Negara Lingkungan Hidup bekerjasama dengan para Steakholder, menggulirkan Program Adiwiyata ini dengan harapan dapat mengajak warga sekolah melaksanakan proses belajar mengajar materi lingkungan hidup dan turut berpartisipasi melestarikan serta menjaga lingkungan hidup di sekolah dan sekitarnya. ${ }^{9}$

Program adiwiyata diharapkan dapat menciptakan kondisi yang nyaman dalam pembelajaran serta timbulnya tanggung jawab lingkungan dalam rangka pembangunan berkelanjutan. Lingkungan yang bersih dan nyaman diyakini akan menambah semangat belajar serta menciptakan kondisi yang tidak membosankan. Sekolah yang peduli dan berbudaya lingkungan akan menciptakan kebijakan-kebijakan dalam mengupayakan perlindungan terhadap lingkungannya. Selain itu, sekolah yang peduli dan berbudaya lingkungan akan mengurangi dampak kerusakan lingkungan melalui pemeliharaan serta pengelolaan lingkungan yang dilakukan secara bijaksana dan sesuai dengan prosedurnya.

Program sekolah Adiwiyata bertujuan untuk menanamkan kecintaan warga sekolah pada lingkungan hidupnya, termasuk menanamkan sikap dan perilaku yang peduli dan berbudaya lingkungan. Wujud kepedulian sekolah tercermin dari upaya warga sekolah mewujudkan pengelolaan lingkungan sekolah dengan prinsip-prinsip

\footnotetext{
${ }^{8}$ Erwati Aziz, Upaya Pelestarian Lingkungan Hidup Melalui Pendidikan Islam (Yogyakarta: Pustaka Belajar,2013), 46.

${ }^{9}$ Desy, Priyanto, \& Supratiwi. "Evaluasi Program Adiwiyata di SMAN 11 Semarang” Jurnal Ilmu Pemerintahan Volume 1, Nomor 1 (2013), 02.
} 
ramah lingkungan. Warga sekolah adalah mulai dari Kepala Sekolah, Guru, seluruh siswa-siswi, petugas kebersihan, petugas keamanan dan Komite Sekolah. ${ }^{10}$

Program Adiwiyata memiliki empat aspek di dalam pelaksanaannya, antara lain aspek kebijakan sekolah berwawasan lingkungan, aspek kurikulum sekolah berbasis lingkungan, aspek pengelolaan sarana prasarana pendukung sekolah yang ramah lingkungan, dan aspek kegiatan berbasis partisipatif. ${ }^{11}$

MTs Negeri 2 Pamekasan yang terletak di Jl. Gatot Koco No.11 Desa Kolpajung, Kecamatan Pamekasan, Kabupaten Pamekasan, yang memiliki Visi: Terwujudnya warga madrasah yang beriman dan bertakwa, menguasai ilmu dan teknologi, peduli pelestarian lingkungan, mampu mencegah pencemaran dan kerusakan lingkungan hidup. MTs Negeri 2 Pamekasan telah terpilih menjadi sekolah adiwiyata sejak tahun 2015 tingkat Kabupaten atau Kota, tahun 2016 terpilih menjadi sekolah adiwiyata tingkat Propinsi dan sekarang ini tahun 2019 akan mengikuti sekolah adiwiyata tingkat Nasional. Dalam perjalanan menuju sekolah adiwiyata secara ideal berkemungkinan membutuhkan waktu relatif panjang, sehingga butuh kepeloporan dan perencanaan yang matang serta kesinambungan upaya kerja keras segenap warga sekolah, baik itu kepala sekolah, guru dan siswa. ${ }^{12}$

Adapun Misi MTs Negeri 2 Pamekasan adalah: a) Memahami dan mengamalkan ajaran Islam dengan benar, b) Menyelenggarakan peningkatan kualitas dan pendidik dan tenaga kependidikan yang professional, c) melaksankan pembelajaran dan bimbingan secara efektif dan efesien, d) menyelenggarakan sistem manajemen madrasah yang profesional, tranparan dan akuntabel, e) menguasai ilmu dan teknologi yang mampu memcegah pencemaran dan kerusakan lingkungan hidup, f) membudidayakan tanaman dimadrsah secara alami dan berteknologi, g) mewujudkan peduli dan pelestarian lingkungan dan pengendalian kerusakan lingkungan. ${ }^{13}$

Berdasarkan hasil pengamatan penulis, MTs Negeri 2 Pamekasan merupakan madrasah adiwiyata se-kabupaten pamekasan yang juga mampu memelihara lingkungan madrasah dengan tumbuh-tumbuhan dan pohon-pohon yang hijau dengan melestarikan penghijauan di lingkungan madrasah, sehingga madrasah akan memiliki ciri khas tersendiri. Selain itu, terdapat sumur serapan dalam artian jika turun hujan karena ada banyaknya pafing di lembaga maka bagaimana air hujan tersebut akan hanya menyerap dibumi madrasah, dengan tujuan air tersebut tidak terbuang sia-sia bisa dimanfaatkan untuk menyiram tanaman dan pohon- pohon yang terdapat di lembaga.

MTs Negeri 2 Pamekasan terpilih menjadi sekolah adiwiyata dikarenakan sekolah tersebut salah satunya mempunyai lingkungan yang indah dan bersih. Berkaitan dengan keempat komponen program adiwiyata yang harus dilaksanakan dan berkelanjutan, maka sekolah MTs Negeri 2 Pamekasan telah melakukannya sesuai dengan komponen adiwiyata. Hal itu dibuktikan dengan terealisasikannya visi misi yang telah ada di sekolah tersebut. Contoh yaitu program kebijakan berwawasan lingkungan. kebijakan

10 Priyantini, Lisdiana \& Eling. "Evaluasi Partisipasi Siswa dalam Pengelolaan sampah untuk Mendukung Program Skolah Adiwiyata" Jurnal IJC Volume 4, Nomor 1 (2015), 75.

11 Darning, Andreas, \& Sri Ngabekti. "Peran Program Adiwiyata dalam Pengembangan Karakter Peduli Lingkungan Siswa di SMK Negeri 2 Semarang” Jurnal Ilmu Pengetahuan Alam Volume 5, Nomor 1 (2016), 1150.

12 Dian Ratih Megawati, Staf Tata Usaha, Wawancara Langsung, (23 Mei 2019).

13 Bahrur Rosi, Ketua Adiwiyata, Wawancara Langsung, (23 Mei 2019). 
berwawasan lingkungan merupakan salah satu komponen implementasi program adiwiyata. Tujuan dari adanya kebijakan berwawasan lingkungan adalah sebagai acuan dalam mengimplementasikan nilai-nilai peduli lingkungan pada program adiwiyata. ${ }^{14}$

Dalam menerapkan hal tersebut, MTs Negeri 2 Pamekasan telah merubah dan menetapkan visi, misi, dan tujuan sekolah yang memuat upaya perlindungan dan pengelolaan lingkungan hidup. Visi Sekolah MTs Negeri 2 Pamekasan yaitu "Terwujudnya Warga Madrasah yang Beriman dan Bertaqwa, Menguasai Ilmu dan Teknologi, Peduli Pelestarian Lingkungan, Mampu Mencegah Pencemaran dan Kerusakaan Lingkungan Hidup".

Dalam mencapai visi tersebut yang termasuk pada salah satu program adiwiyata dan juga program-program lainnya yang telah terealisasikan dalam sekolah MTs Negeri 2 Pamekasan tentunya guru melakukan perencanaan terlebih dahulu dalam menumbuhkan kesadaran siswa. Perencanaan memegang peranan penting dalam organisasi karena akan menjadi penentu sekaligus memberi arah terhadap tujuan yang ingin dicapai. Perencanaan adalah kegiatan yang berkaitan dengan usaha merumuskan program yang di dalamnya memuat segala sesuatu yang akan dilaksanakan, penentuan tujuan, kebijaksanaan, arah yang akan ditempuh, prosedur dan metode yang akan diikuti dalam usaha pencapaian tujuan. ${ }^{15}$

Berdasarkan adanya pelaksanaan program adiwiyata tersebut, tentunya guru MTs Negeri 2 Pamekasan telah melakukan Manajemen strategis dalam menumbuhkan kesadaran siswa untuk mempertahankan program adiwiyata, sehingga sekolah ini terpilih menjadi sekolah adiwiyata tingkat kabupaten atau kota. Untuk itu, peneliti tertarik untuk melakukan penelitian lebih lanjut dan ingin mengetahui lebih mendalam mengenai hal tersebut. Oleh sebab itu peneliti mengangkat judul tentang "Manajemen Strategi Guru dalam Menumbuhkan Kesadaran Siswa Untuk Mempertahankan Program Adiwiyata di MTs Negeri 2 Pamekasan"

\section{METODE PENELITIAN}

Penelitian ini menggunakan pendekatan kualitatif dengan jenis Deskriptif. Sumber data yang diperoleh melalui wawancara, observasi dan dokumentasi. Informannya adalah kepala madrasah, dan bendahara sekolah. Sedangkan pengecekan keabsahan data dilakukan melalui perpanjangan pengamatan, peningkatan penekunan, triangulasi, dan analisis Data.

\section{HASIL DAN PEMBAHASAN}

1. Manajemen strategi guru dalam menumbuhkan kesadaran siswa untuk mempertahankan program adiwiyata di MTs Negeri 2 Pamekasan

Berdasarkan hasil temuan peneliti, manajemen strategi guru dalam menumbuhkan kesadaran siswa untuk mempertahankan program adiwiyata di MTs Negeri 2 Pamekasan menggunakan fungsi manajemen yaitu perencanaan, pelaksanaan dan evaluasi dengan deskripsi berikut ini.

Perencanaan merupakan suatu kegiatan yang dilakukan untuk merancang suatu kegiatan atau program yang terdiri dari apa yang akan dikerjakan, apa yang

14 Kadorodasih, "Implementasi Pendidikan Lingkungan Hidup Melalui Program Adiwiyata Di SDN Giwangan Yogyakarta." Jurnal Hanata Widya, Volume 6 Nomor 4 (2017) 45.

15 Saefullah. Manajemen Pendidikan Islam (Bandung: CV. Pustaka Setia, 2013), 211. 
dibutuhkan, biaya yang dibutuhkan dan hal yang lainnya yang menunjang kegiatan. ${ }^{16}$ Sedangkan dalam manajemen strategi guru dalam menumbuhkan kesadaran siswa untuk mempertahankan program adiwiyata di MTs Negeri 2 Pamekasan perencanaan dalam manajemen strategi guru dalam menumbuhkan kesadaran siswa untuk mempertahankan program adiwiyata di MTs Negeri 2 Pamekasan yaitu guru memasukkan program-program adiwiyata ke dalam Rencana Pembelajaran contohnya seperti memasukkan program adiwiyata kedalam RPP dan silabus.

Pelaksanaan yaitu salah satu fungsi manajemen yang berfungsi untuk merealisasikan hasil perencanaan dan pengorganisasian. Actuating adalah upaya untuk menggerakkan atau mengarahkan tenaga kerja serta mendayagunakan fasilitas yang ada yang dimaksudkan untuk melaksanakan pekerjaan secara bersama. ${ }^{17}$ Pelaksanaan dalam manajemen strategi guru dalam menumbuhkan kesadaran siswa untuk mempertahankan program adiwiyata di MTs Negeri 2 Pamekasan dalam setiap pelaksanaan pembelajaran guru menegaskan sikap-sikap adiwiyata, sikap kebersihan dan sikap peduli lingkungan kepada seluruh siswa. Contohnya sebelum proses pembelajaran berlangsung guru memberikan waktu 1-3 menit kepada siswa untuk melihat keadaan kelas sudah bersih atau belum, jika di kelas tersebut masih ada sampah maka guru memerintahkan kepada siswa untuk membuangnya. Dan itu diterapkan setiap pergantian mata pelajaran. Dari strategi-strategi yang telah ditetapkan kami melaksanakannya setiap pergantian mata pelajaran.

Evaluasi merupakan suatu upaya penilaian secara obyektif terhadap peraihan tujuan yang telah ditetapkan sebelumnya. Evaluasi diadakan setiap 3 bulan satu kali. Evaluasi dalam manajemen strategi guru dalam menumbuhkan kesadaran siswa untuk mempertahankan program adiwiyata di MTs Negeri 2 Pamekasan dilakukan untuk mengukur sejauh mana sasaran dicapai.

\section{Faktor Pendukung dan Penghambat manajemen Strategi Guru dalam menumbuhkan kesadaran siswa untuk mempertahankan program adiwiyata di MTs Negeri 2 Pamekasan}

Berdasarkan hasil wawancara, dan observasi yang telah dilakukan oleh peneliti, faktor pendukung manajemen strategi guru dalam menumbuhkan kesadaran siswa untuk mempertahankan program adiwiyata di MTs Negeri 2 Pamekasan adalah sebagai berikut: (a) Kerjasama dan sama kerja antara seluruh elemen sekolah baik itu siswa, guru, dan seluruh warga sekolah. (b) Mengikuti peraturan yang ada disekolah seperti membuang sampah pada tempatnya. (c) Menciptakan POKJA, (d) Membentuk jadwal piket pemantau kebersihan baik kebersihan kelas maupun halaman sekolah, (e) Siswa memang berasal dari sekolah dasar adiwiyata, (f) Semua guru menerapkan program adiwiyata kedalam pembelajaran dan kehidupan berorganisasi.

Sedangkan faktor penghambat yang mempengaruhi manajemen Strategi Guru dalam menumbuhkan kesadaran siswa untuk mempertahankan program adiwiyata yaitu: (a) ketidak pedulian guru terhadap program dan perilaku yang mengarah

16 Diyasika Ulinafiah dan Novan Ardy Wiyani. "Penciptaan Layanan Prima Melalui Penerapan Sistem Informasi Manajemen di Perpustakaan IAIN Purwokerto." re-JIEM (Research Journal of Islamic Education Management) 2, no. 2 (2019): 223-239.

17 Ibid. 
kepada program adiwiyata, contohnya seperti memulai kegiatan pembelajaran dalam situasi kelas kotor, membiarkan siswa membuang sampah sembarangan, dan (b) faktor keluarga karena keluarga disini adalah tempat pendidikan pertama dari seorang anak yang kemudian dikembangkan di lingkungan sekolah, Jadi ketika di ruang lingkup keluarga bisa membentuk rasa kecintaan terhadap lingkungan dalam diri siswa, maka akan memudahkan bagi guru untuk menumbuhkan, mengembangkan dan mempertahankan program adiwiyata.

\section{Pembahasan}

Dalam hal ini peneliti ingin membahas lebih jauh lagi tentang data yang didapatkan di lapangan, dimana untuk mendapatkan data yang valid. Selain itu peneliti ingin menggabungkan beberapa teori yang sudah di paparkan dalam bab sebelumnya yang mana hal ini di perlukan untuk menjawab dari fokus penelitian.

\section{Manajemen Strategi yang digunakan oleh guru dalam menumbuhkan kesadaran siswa untuk Mempertahankan Program Adiwiyata di MTs Negeri 2 Pamekasan.}

Manajemen adalah mencapai tujuan organisasional dengan tepat melaksanakan tugas dan dengan baik menggunakan sumber-sumber melalui pelaksanaan fungsifungsi manajemen yang terdiri dari perencanaan, pengorganisasian, pengadaan sumberdaya, pengkomunikasian, pemimpinan, pemotivasian, dan pengendalian atau pengontrolan. $^{18}$

Manajemen strategi merupakan serangkaian proses atau tahapan. Proses manajemen strategi menyediakan kerangka gabungan bagi para manajer untuk menangani berbagai masalah yang unik untuk mengidentifikasi peluang baru dengan lebih mudah dan untuk memperkirakan kekuatan yang dapat digunakan dan kelemahan yang harus diperbaiki. Proses ini dimaksudkan untuk memadukan antara misi dan tujuan yang dihubungkan dengan lingkungan internal dan eksternal, kekuatan, kelemahan, ancaman dn peluang untuk memilih strategi yang tepat dan menentukan tercapainya strategi yang diinginkan. ${ }^{19}$

Strategi merupakan rangkaian kegiatan yang dilakukan untuk mencapai tujuan. Strategi memegang peranan penting dalam pencapaian tujuan sebab strategi berisi tentang cara, langkah dan berbagai upaya yang dilakukan untuk mencapai tujuan.setiap kegiatan dalam menerapkan program harus diikuti dengan penerapan strategi yang tepat. $^{20}$

Guru sebagai pendidik ataupun pengajar merupakan factor penentu kesuksesan setip usaha pendidikan. Itulah sebabnya setiap perbincangan mengenai pembaruan kurikulum, pengadaan alat-alat belajar sampai pada criteria sumber daya manusia yang dihasilkan oleh usaha pendidikan, selalu bermuara pada guru. Hal ini menunjukkan betapa signifikan posisi guru dalam dunia pendidikan. ${ }^{21}$

18 Robby Arini and Achmad Muhlis. "MANAJEMEN STRATEGIK MUTU REKRUTMEN TENAGA KEPENDIDIKAN DI INSTITUT AGAMA ISLAM NEGERI MADURA." re-JIEM (Research Journal of Islamic Education Management) 3, no. 1 (2020): 29-41.

19 Amirullah. Manajemen Strategi Teori-Konsep-Kinerja, (Jakarta: Mitra Wacana Media, 2015), 15.

20 Mohammad Saroni. Analisi dan Strategi Meningkatkan Daya Saing Sekolah, (Jogjakarta : Arr-Ruzz Media, 2017), 245.

21 Muhibbin Syah. Psikologi Pendidikan (Bandung: PT. Remaja Rosdakarya, 2009), 222-223. 
Perlu kita ketahui bahwa strategi dan metode adalah hal yang berbeda, srategi menunjuk pada sebuah perencanaan untuk mencapai sesuatu, sedangkan metode adalah cara yang dapat digunakan untuk melaksanakan strategi.

Pekerjaan mengajar merupakan pekerjaan yang kompleks dan sifatnya dimensional. Berkenaan dengan hal tersebut guru paling sedikit harus menguasai berbagai tekhnik yang erat hubungannya dengan kegitan penting dalam pengajaran. Urutan pembelajaran yang baik selalu melibatkan keputusan guru berdasarkan berbagai tugas.

Kerangka perencanaan dan implementasi pengajaran melibatkan urutan langkah-langkah yang sangat penting bagi para guru dalam mempersiapkan pelaksanaan rencana pengajaran. $^{22}$

Kesadaran Siswa merupakan sikap mental siswa dalam memandang sesuatu. Dalam sikap mental ini maka siswa akan berprilaku sebagaimana sikap mental yang dianutnya. Seperti halnya siswa mempunyai kesadaran bahwa lingkungan yang bersih akan menjamin proses belajar mengajar yang berlangsung di lembaga pendidikan tersebut akan menjadi lebih efektif, sehingga seluruh warga sekolah berupaya untuk selalu menjaga dan mempertahankan kebersihan lingkungan sekolah.

Ada beberapa strategi untuk menumbuhkan kesadaran siswa yaitu sebagai berikut : (a) Menjelaskan tujuan belajar kepada peserta didik pada permulaan belajar mengajar seharusnya terlebih dahulu seorang guru menejelaskan mengenai tujuan yang akan dicapai. (b) Hadiah, berikan hadiah untuk siswa yang berprestasi. Hal ini akan memacu semangat mereka untuk bisa belajar lebih giat lagi. Disamping itu siswa yang belum berprestasi akan termotivasi untuk bisa mengejar siswa yang berprestasi. (c) Saingan/kompetisi yaitu guru berusaha mengadakan persaingan diantara siswanya untuk meningkatkan prestasi belajarnya. (d) Pujian yaitu sudah sepantasnya siswa yang berprestasi untuk diberikan penghargaan atau pujian, tentunya pujian yang bersifat membangun. (e) Hukuman yaitu diberikan kepada siswa yang berbuat kesalahan saat proses belajar mengajar, hukuman ini diberikan dengan harapan agar siswa tersebut mau merubah diri dan berusaha memacu motivasi belajarnya. (f) Membangkitkan dorongan kepada peserta didik untuk belajar strateginya adalah dengan memberikan perhatian maksiaml kepada peserta didik. (g) Membentuk kebiasaan belajar yang baik. (h) Membantu kesulitan belajar peserta didik baik secara individual atau kelompok. (i) Menggunakan metode yang bervariasi. (j) Menggunakan media yang baik serta harus sesuai dengan tujuan pembelajaran. $^{23}$

Adiwiyata mempunyai pengertian sebagai tempat yang baik dan ideal dimana dapat diperoleh segala ilmu pengetahuan dan berbagai norma serta etika yang dapat menjadi dasar manusia menuju terciptanya kesejahteraan hidup kita dan menuju kepada cita-cita pembangunan berkelanjutan.

Tujuan program Adiwiyata adalah mewujudkan warga sekolah yang bertanggung jawab dalam upaya perlindungan dan pengelolaan lingkungan hidup melalui tata kelola sekolah yang baik untuk mendukung pembangunan berkelanjutan. Adiwiyata merupakan salah satu program Kementerian Lingkungan Hidup dalam

22 Abdul Majid, Perencanaan Pembelajaran (Bandung: PT. Remaja Rosdakarya, 2016), 92.

23 Pupuh \& Sobry Sutikno, Strategi Belajar Mengajar, (Bandung: PT. Refika Aditama, 2007), 21. 
rangka mendorong terciptanya pengetahuan dan kesadaran warga sekolah dalam upaya pelestarian lingkungan hidup. Diharapkan setiap warga sekolah ikut terlibat dalam kegiatan sekolah menuju lingkungan yang sehat dan menghindari dampak lingkungan yang negatif. ${ }^{24}$

Program Adiwiyata adalah salah satu program Kementrian Negara Lingkungan Hidup dalam rangka mendorong terciptanya pengetahuan dan kesadaran warga sekolah dalam upaya pelestarian lingkungan hidup. Dalam pelaksanaannya Kementrian Negara Lingkungan Hidup bekerjasama dengan para steakholder, menggulirkan Program Adiwiyata ini dengan harapan dapat mengajak warga sekolah melaksanakan proses belajar mengajar materi lingkungan hidup dan turut berpartisipasi melestarikan serta menjaga lingkungan hidup di sekolah dan sekitarnya. $^{25}$

Program Adiwiyata memiliki empat aspek di dalam pelaksanaannya, antara lain aspek kebijakan sekolah berwawasan lingkungan, aspek kurikulum sekolah berbasis lingkungan, aspek pengelolaan sarana prasarana pendukung sekolah yang ramah lingkungan, dan aspek kegiatan berbasis partisipatif. Aspek-aspek tersebut berperan dalam mengkondisikan lingkungan sekolah untuk membiasakan perilaku peduli lingkungan siswa. Pembiasaan perilaku peduli lingkungan akan membentuk karakter peduli lingkungan siswa. ${ }^{26}$

2. Faktor Pendukung dan Penghambat manajemen Strategi Guru dalam menumbuhkan kesadaran siswa untuk mempertahankan program adiwiyata di MTs Negeri 2 Pamekasan

Dalam rangka pelestarian lingkungan, keterlibatan semua komponen masyarakat mutlak diperlukan. Untuk mewujudkan sekolah yang peduli dan berbudaya lingkungan, warga sekolah perlu dilibatkan dalam berbagai aktivitas pembelajaran lingkungan hidup. Selain itu sekolah juga diharapkan melibatkan masyarakat disekitarnya dalam melakukan berbagai kegiatan yang memberikan manfaat baik bagi warga sekolah, masyarakat maupun lingkungannya.

Mensosialisasikan beberapa kegiatan utama dengan pendekatan pada siswa sangat penting di lakukan guna mendapatkan dukungan yang sempurna sehingga menciptakan kesepakatan yang mutlak bahwa sekolah tersebut benar-benar sekolah berwawasan lingkungan bukan hanya tertera dalam sampul dokumen. ${ }^{27}$

Penyiapan sumber daya manusia yang potensial melalui pendidikan lingkungan adalah salah satu faktor yang diperlukan dalam upaya mewujudkan pembangunan yang berkelanjutan. Pendidikan lingkungan adalah pendidikan yang mengembangkan

24 Ika Maryani, "Evaluasi Pelaksanaan Program Sekolah Adiwiyata ditinjau dari Aspek Kegiatan Partisipatif di SDN Ungaran 1 Yogyakarta”, Jurnal Pemikiran dan Pengembangan SD, Vol. 1, No. 2, (2014), 173.

25 Desy, Priyatnio \& Supratiwi, "Evaluasi Program Adiwiyata di SMAN 11 Semarang”, Jurnal Ilmu Pemerintahan, Vol. 1, No. 1, (2013), 02.

26 Darning, Andreas \& Sri, "Peran Program Adiwiyata dalam Pengembangan Karakter Peduli Lingkungan Siswa di SMK Negeri 2 Semarang”, Unnes Science Education Journal, Vol. 5, No. 1, (2016), 1150.

27 Ellen Landriany, "Implementasi Kebijakan Adiwiyata dalam Upaya Mewujudkan Pendidikan lingkungan Hidup di SMA Kota Malang”, Jurnal Kebijkan dan Pengembangan Pendidikan, Vol. 2, No. 1, (2014), 85. 
kesadaran manusia atas ketergantungan pada lingkungan dan tanggungjawabnya untuk memelihara kelestarian dan keharmonisan lingkungan. ${ }^{28}$

Pendidikan yang diterapkan di lingkungan internal sistem kelembagaan hanyalah sebagian dari tanggung jawab kepala lembaga pendidikan sebagaimanajer pendidikan Para pengelolalembaga pendidikan merupakan eksekutifmodern saat ini harus mampu mengamatidan merespon segenap tantangan yang dimunculkan oleh lingkungan eksternal baik yang dekat maupun yang jauh.

Lingkungan eksternal dekat adalah lingkungan yang mempunyai pengaruh langsung pada operasional lembaga pendidikan, seperti berbagai potensi dan keadaan dalam bidang pendidikan yang menjadi konsentrasi usaha sekolah itu sendiri, situasi persaingan, situasi pelanggan pendidikan, dan pengguna lulusan. Kesemuanya berpengaruh pada penentuan strategi yang diperkirakan mendukung penyelenggaraan pendidikan mencapai tujuannya. Lingkungan eksternal yang jauh adalah berbagai kekuatan dan kondisi yang muncul di luar lingkungan eksternal yang dekat meliputi keadaan sosial ekonomi, politik, keamanan nasional, perkembangan teknologi, dan tantangan global. Secara tidak langsung berpengaruh terhadap penyelenggaraan sistem pendidikan di suatu lembaga pendidikan. ${ }^{29}$

Faktor lingkungan internal dan eksternal perlu diantisipasi, dipantau, dinilai, dan disertakan sedemikian rupa ke dalam proses pengambilan keputusan eksekutif. Para pengambil keputusan, termasuk di dalamnya kepala lembaga maupun pengelola pendidikan lainnya seringkali terpaksa mengalahkan tuntutan kegiatan interen dan eksteren lembaga pendidikan demi melayani bermacam kepentingan seperti urusan rutin, dinas, bekerja harus selalu di bawah petunjuk atau pedoman kerja yang ditetapkan oleh birokrasi tanpa mempertimbangkan kebutuhan eksternal organisasi yang terus berubah, sehingga proses pengambilan keputusan seringkali tidak maksimal dalam menghasilkan keputusan-keputusan strategis.

Akibatnya persoalan aktual lembaga pendidikan yang dihadapi tidak dapat terselesaikan secara maksimal. Pengamatan dan penilaian yang dilakukan secara simultan terhadap lingkungan eksternal dan internal lembaga pendidikan memungkinkan para pengelola pendidikan mampu mengidentifikasi berbagai jenis peluang yang ada untuk dapat merumuskan dan mengimplementasikan berbagai rencana pendidikan secara berhasil. Rancangan yang bersifat menyeluruh ini dapat dilakukan melalui proses tindakan yang dikenal sebagai analisis lingkungan strategik.

Penghargaan sebagai sekolah adiwiyata dicapai melalui sejumlah tahapan. Oleh karena itu sekolah harus mengetahui faktor pendukung dan faktor penghambat dalam memperoleh penghargaan tersebut.

Faktor pendukung internal antara lain : (a) sekolah memiliki tim adiwiyata sekolah, (b) memiliki visi, misi dan tujuan sekolah yang berwawasan lingkungan, (c) alokasi anggaran, (d) kurikulum PLH, dan (e) komitmen warga sekolah.

Sedangkan Faktor pendukung eksternal antara lain : (a) mengimbaskan program adiwiyata pada sekolah lain, (b) mendukung adipura, (c) menjadi

28 Sumarlin Dkk, "Persepsi dan Kepedulian Siswa Terhadap Pengelolaan Lingkungan Sekolah Melalui Program Adiwiyata", Jurnal Geografi Indonesia, Vol. 27, No. 1, (2013), 39.

29 Mohamad Khoirul Umam, "Analisis Lingkungan Strategik dalam Corak Penyelenggaraan Pendidikan Islam”, Jurnal Al-Hikmah, Vol. 4, No. 2, (2016), 01. 
narasumber, (d) mendapatkan bantuan sarpras, (e) memiliki lulusan yang berkualitas, dan (f) menjadi sekolah tujuan utama bagi siswa baru.

Adapun Faktor penghambat internal antara lain : (a) kurangnya kemitraan dengan pihak luar, (b) partisipasi tenaga pendidik dan peserta didik untuk mengikuti aksi lingkungan masih kurang, (c) kemampuan tenaga pendidik dalam memanfaatkan teknologi informasi dalam menunjang pembelajaran PLH masih rendah, (d) pemanfaatan sarpras belum optimal. Faktor penghambat eksternal antara lain: (a) mutasi kepala sekolah dan guru, (b) dukungan dan pembinaan dari Dinas Pendidikan belum maksimal, (c) belum adanya regulasi yang mendukung program adiwiyata, (d) kurangnya monitoring dan evaluasi. ${ }^{30}$

\section{KESIMPULAN}

Dari paparan data dan temuan penelitian serta pembahasan pada bab-bab sebelumnya, maka dapat diambil kesimpulan sebagai berikut:

Manajemen strategi guru dalam menumbuhkan kesadaran siswa untuk mempertahankan program adiwiyata yaitu 1) Perencanaan yaitu guru memasukkan program-program adiwiyata ke dalam Rencana Pembelajaran contohnya seperti memasukkan program adiwiyata kedalam RPP dan silabus. 2) Pelaksanaan yaitu dalam setiap pelaksanaan pembelajaran guru menegaskan sikap-sikap adiwiyata, sikap kebersihan dan sikap peduli lingkungan kepada seluruh siswa. Contohnya sebelum proses pembelajaran berlangsung guru memberikan waktu 1-3 menit kepada siswa untuk melihat keadaan kelas sudah bersih atau belum, jika di kelas tersebut masih ada sampah maka guru memerintahkan kepada siswa untuk membuangnya. Dan itu diterapkan setiap pergantian mata pelajaran. 3) dari strategi-strategi yang telah ditetapkan kami melaksanakannya setiap pergantian mata pelajaran. 4) Baru setelah itu diadakan yang namanya evaluasi setiap 3 bulan satu kali. Evaluasi ini dilakukan untuk mengukur sejauh mana sasaran dicapai.

Adapun faktor pendukung dan penghambat yang mempengaruhi manajemen Strategi Guru dalam menumbuhkan kesadaran siswa untuk mempertahankan program adiwiyata, faktor pendukungnya yaitu: 1) Kerjasama dan sama kerja antara seluruh elemen sekolah baik itu siswa, guru, dan seluruh warga sekolah. 2) Mengikuti peraturan yang ada disekolah seperti membuang sampah pada tempatnya. 3) Menciptakan POKJA, 4) membentuk jadwal piket pemantau kebersihan baik kebersihan kelas maupun halaman sekolah, 5) Siswa memang berasal dari sekolah dasar adiwiyata, 6) Semua guru menerapkan program adiwiyata kedalam pembelajaran dan kehidupan berorganisasi. Sedangkan Faktor Penghambatnya yaitu : 1) Ketidak pedulian guru terhadap program dan perilaku yang mengarah kepada program adiwiyata, contohnya seperti memulai kegiatan pembelajaran dalam situasi kelas kotor, membiarkan siswa membuang sampah sembarangan, 2) Faktor keluarga karena keluarga disini adalah tempat pendidikan pertama dari seorang anak yang kemudian dikembangkan di lingkungan sekolah, Jadi ketika di ruang lingkup keluarga bisa membentuk rasa kecintaan terhadap lingkungan dalam diri siswa, maka akan memudahkan bagi guru untuk menumbuhkan, mengembangkan dan mempertahankan program adiwiyata.

30 Ratna Dkk, "Strategi Pembinaan Sekolah Adiwiyata di Kota Batu", Jurnal Wacana, Vol. 18, No. 4, (2015), 243. 


\section{DAFTAR PUSTAKA}

Ahmad, Abu \& Nur Uhbiyati. Ilmu Pendidikan, Jakarta: PT. Rineka Cipta. 2007.

Amirullah. Manajemen Strategi Teori-Konsep-Kinerja, Jakarta: Mitra Wacana Media. 2015.

Arikunto, Suharsimi. Prosedur Penelitian Suatu Pendekatan Praktik, Jakarta: Rineka Cipta. 2013.

Arini, Robby, and Achmad Muhlis. "MANAJEMEN STRATEGIK MUTU REKRUTMEN TENAGA KEPENDIDIKAN DI INSTITUT AGAMA ISLAM NEGERI MADURA." re-JIEM (Research Journal of Islamic Education Management) 3, no. 1 (2020): 29-41.

Aziz, Abdul. Pengantar Manajemen dan Substansi Administrasi Pendidikan, Surabaya: Anggota IKAPI. 2017.

Aziz, Erwati. Upaya Pelestarian Lingkungan Hidup Melalui Pendidikan Islam, Yogyakarta: Pustaka Belajar. 2013.

Barnawi, Mohammad Arifin. Etika dan Profesi Kependidikan, Jogjakarta: Ar-Ruzz Media. 2012.

Basrowi \& Suwandi. Memahami Penelitian Kualitatif, Jakarta: Rineka Cipta. 2008.

Darning, Andreas, \& Sri Ngabekti. "Peran Program Adiwiyata dalam Pengembangan Karakter Peduli Lingkungan Siswa di SMK Negeri 2 Semarang" Jurnal Ilmu Pengetahuan Alam, Volume 5, Nomor 1. 2016.

Desy, Priyanto, \& Supratiwi. "Evaluasi Program Adiwiyata di SMAN 11 Semarang" Jurnal Ilmu Pemerintahan, Volume 1, Nomor 1.

Endang, Dkk. 2018. Sekolah Adiwiyata Panduan Implementasi Adiwiyata Mandiri di Sekolah, Jakata: Erlangga. 2013.

Handoko, Hani. Manajemen, Yogyakarta: Anggota IKAPI. 2009.

Iriantara, Yosal. Humas Sekolah, Bandung: Simbiosa Rekatama Media. 2013.

Kadorodasih, "Implementasi Pendidikan Lingkungan Hidup Melalui Program Adiwiyata Di SDN Giwangan Yogyakarta." Jurnal Hanata Widya, Volume 6, Nomor 4. 2017.

Karwati, Euis dan Donni Juni Priansa. Manajemen Kelas (Classroom Manajemen); Guru Pofesional Yang Inspiratif, Kreatif, Menyenangkan, Dan Berprestasi, Bandung: Alfabeta. 2015.

Khoirul, Muhamad Umam, "Analisis Lingkungan Strategik dalam Corak Penyelenggaraan Pendidikan Islam" Jurnal Al-Hikmah, Volume 4, Nomor 2. 2016.

Khori, Ahmad. "Manajemen Strategik dan Mutu Pendidikan Islam" Jurnal Manajemen Pendidikan Islam, Volume 1, Nomor 1. 2016.

Kusnawan, Aep. "Perencanaan Pendidikan Tinggi Dakwah Islam" Jurnal Ilmu Dakwah, Volume 4, Nomor 15. 2010.

Landriany, Ellen. "Implementasi Kebijakan Adiwiyata dalam Upaya Mewujudkan Pendidikan lingkungan Hidup di SMA Kota Malang”, Jurnal Kebijkan dan Pengembangan Pendidikan, Volume. 2, Nomor. 1. 2014.

Lisdiana, Priyantini, \& Eling. "Evaluasi PartisipasiSiswa dalam Pengelolaan sampah untuk Mendukung Program Skolah Adiwiyata" Jurnal IJC, Volume 4, Nomor 1. 2015.

Majid, Abdul. Perencanaan Pembelajaran, Bandung: PT. Remaja Rosdakarya. 2016. 
Manab, Abdul. Manajemen Kurikulum Pembelajaran di Madrasah, Yogyakarta: Kalimedia. 2015.

Maryani, Ika. "Evalusi Pelaksanaan Program Sekolah Adiwiyata ditinjau dari Aspek Kegiatan Partisipatif di SDN Ungaran 1 Yogyakarta" Jurnal Pemikiran dan Pengembangan SD, Volume 1, Nomor 3. 2014.

Moleong, J. Lexy. Metodologi Penelitian Kulitatif, Bandung: Remaja Rosda Karya. 2005.

Muslicha, Anisa. "Metode Pengajaran dalam Pendidikan Lingkungan Hidup pada Siswa Sekolah Dasar pada Sekolah Adiiyata di DKI Jakarta" Jurnal Pendidikan, Volume 16, Nomor 2. 2015.

Naim, Ngainun. Menjadi Guru Inspiratif, Yogyakarta: Pustaka Pelajar. 2009.

Pupuh \& Sobry Sutikno. Strategi Belajar Mengajar, Bandung: PT. Refika Aditama. 2007.

R. Terry, George Leslie W. Rue. Dasar-dasar Manajemen, Jakarta: PT. Bumi Aksara. 1992.

Ratna Dkk. "Strategi Pembinaan Sekolah Adiwiyata di Kota Batu", Jurnal Wacana, Volume. 18, Nomor. 4. 2015.

Saefullah. Manajemen Pendidikan Islam, Bandung: CV. Pustaka Setia. 2013.

Sanjaya, Wina. Strategi Pembelajaran Berorientasi Standar Proses Pendidikan, Jakarta:Kencana Prenadamedia Group. 2006.

Saroni, Mohammad. Analisis dan Strategi Meningkatkan Daya Saing Sekolah, Jogjakarta : Arr-Ruzz Media. 2017.

Silaban, J. Susi. "Implementasi Program Adiwiyata di SMP Negeri 20 Pekanbaru" Jurnal FISIP, Volume 4, Nomor 2. 2017.

Sugiyono. Penelitian Kualitatif dan Kuantitatif dan R dan D, Bandung: Alfabeta. 2011.

Sumarlin Dkk. "Persepsi dan Kepedulian Siswa Terhadap Pengelolaan Lingkungan Sekolah Melalui Program Adiwiyata", Jurnal Geografi Indonesia, Volume. 27, Nomor. 1.2013.

Syah, Muhibbin. Psikologi Pendidikan, Bandung: PT. Remaja Rosdakarya. 2009.

Ulinafiah, Diyasika, and Novan Ardy Wiyani. "Penciptaan Layanan Prima Melalui Penerapan Sistem Informasi Manajemen di Perpustakaan IAIN Purwokerto." reJIEM (Research Journal of Islamic Education Management) 2, no. 2 (2019): 223239. 